\title{
Apresentação do dossiê: Complexidade e transdisciplinaridade
}

Em cenários emblemáticos de pandemia, desenhamos horizontes para celebrar a vida e a obra de um dos pensadores mais influentes nas ciências, no contemporâneo: Edgar Morin. Crítico da fragmentação do conhecimento, transdisciplinar e autodidata, Morin foi convidado pela Unesco, no último ano do século passado, para refletir sobre a educação do novo milênio. $\mathrm{Na}$ inspiração de suas considerações iniciais, o conjunto de reflexões circulou entre educadores dos diversos continentes para conferir e oferecer contribuições e, no ano 2000, como resultado desse intenso processo, é publicada a obra Os sete saberes necessários à educação do futuro.

Vinte anos depois, a obra é expressivamente atual. Sua composição indica saberes fundamentais que a educação não pode se furtar de promover. São eles: "As cegueiras do conhecimento: o erro e a ilusão; Os princípios do conhecimento pertinente; Ensinar a condição humana; Ensinar a identidade terrena; Enfrentar as incertezas; Ensinar a compreensão e, A ética do gênero humano”. Uma fina percepção revela que tais saberes não representam conteúdos disciplinares; antes, sugerem problemas essenciais.

Com o desdobramento da inédita crise planetária que ilustra o calendário de 2020, o pensamento complexo de Morin permite melhor compreender e enfrentar as incertezas, os acasos, as imprevisibilidades da vida. Religar os diversos tipos de pensamento estimula e favorece a aprendizagem de fenômenos multidimensionais. De fato, a transdisciplinaridade emerge na ciência como um modo de enfrentar a cristalização da fragmentação e da disciplinarização.

Com este dossiê intitulado "Complexidade e transdisciplinaridade”, o Programa de Pós-Graduação em Educação e a Revista 
Educação \& Linguagem da Universidade Metodista de São Paulo alcançam três objetivos: 1) homenagear o autor na celebração de seus 99 anos de uma vida constituída com "amor, poesia, sabedoria" - título de um de seus inúmeros livros -, 2) celebrar os 20 anos da publicação da obra, que é uma referência para educadores de todos os níveis, graus, espaços, tempos e, 3) oferecer subsídios relevantes aos docentes, estudantes de pós-graduação e leitores interessados em educação, sobretudo, neste momento de tensão mundial, em que se buscam respostas - imediatas ou não - para o enfrentamento de crescentes desafios.

O dossiê é composto por 16 artigos, de pesquisadores de 24 instituições de ensino, com pesquisas nacionais - dos Estados de Alagoas, Ceará, Rio Grande do Norte, Goiás, Paraná, Santa Catarina e São Paulo - e internacionais - da Espanha (Sevilha e Barcelona), Argentina e Uruguai.

Alguns autores tratam seus temas com destaque particular para "Os sete saberes". Outros os incorporam na prática da pesquisa transdisciplinar, seja nas interfaces com as políticas e gestão em educação, seja na formação de professores, linhas de pesquisa do Programa de Pós-Graduação em Educação da UMESP. Há textos que abordam princípios epistemológicos da Complexidade, ética, valores, política, comunicação, cultura, inclusão, solidariedade. Demais textos apresentam pesquisas aplicadas e/ou desenvolvidas em instituições educacionais e projetos de trabalho de caráter comunitário, hospitalar, de educação formal e não formal.

É nessa religação de saberes que se configuram as ciências da Complexidade, em desdobramentos (in)explicáveis da existência.

Desejamos uma agradável e instigante leitura.

Os organizadores,

Profa. Dra. Izabel Petraglia Prof. Dr. Marcelo Furlin

Inverno de 2020 